\title{
Correspondence
}

\section{Cold baths to keep out the cold?}

\author{
Ian R. Stone \\ University of Kent at Canterbury, Canterbury, Kent, \\ CT2 7NZ
}

\section{Received July 1988}

The interesting note by Stroud entitled "Whence came Bowers' great heat supply?" in the July 1988 issue of Polar Record (p.245) prompts reference to a piece of anecdotal evidence which seems to support the proposition that a degree of cold resistance can be acquired by periods of exposure in advance. This relates to Aubyn Trevor-
Battye, about whom I earlier wrote a Profile (PolarRecord 23(143): 177-82 (1986).

With a companion, Trevor-Battye spent some time in 1894 on Ostrov Kolguyev (Kolguyev Island) in the European Arctic. He noted that his companion felt the cold, which had the effect of making him somnolent, whilehe himself did not. The immunity he ascribed to 'having a cold bath every morning (which) makes one less sensitive' (Trevor-Battye, A. B. R., 1895. Ice-bound on Kolguyev. Westminster, Archibald Constable: 75).

The cold bath is, of course, part of the mythology of the English public school, and it would be interesting for a survey to be made relating cold resistance in explorers to whether or not they were so educated!

\section{Reviews}

\section{JOURNEYMAN GEOGRAPHER}

GRIFFITH TAYLOR: ANTARCTIC SCIENTIST AND PIONEER GEOGRAPHER. Sanderson, Marie. 1988. Ottawa, Carleton University Press. Carleton Library series $145.218 \mathrm{p}$, illustrated, soft cover. ISBN 0-88629006-X. Can\$14.95.

In his old age Griffith Taylor (popularly 'Grif') sat down to write his autobiography Journeyman Taylor. The manuscript numbered 1114 pages and predictably was rejected for publication. Drastically pruned by an editor, it finally reached the bookshops in 1958. As its subtitle, 'the education of a scientist' suggested, it was in no way a rounded life. Twenty-five years after Grif's death comes this reappraisal by a former student from his Toronto days. Professor Sanderson, herself an eminent Canadian geographer, has pursued her researches worldwide and with thoroughness. Grif's papers - personal diaries, voluminous correspondence, abundant notes, along with the published and unpublished oeuvre - have been examined; professional colleagues, friends and relatives have been interviewed. The result is as rounded and balanced a life as one could expect from so ardent an admirer of her subject. It is also pleasing to find due tribute given to the two women without whose support he could not have accomplished a half of what he did; his sister Dorothy (who adored him) and his wife Doris, a sister of the late Sir Raymond Priestley, whom he married in Australia in 1914 and who emerges here as a staunch and loyal supporter of her husband for some 50 years.

Unpublished family papers hint at the genetic debt that Grif owed to his father James, a man of working-class origins whose ambition to escape from his roots led him to New South Wales as government metallurgist. Grif inherited this same ambition to succeed. At the Univer- sity of Syndey he fell under the spell of Edgeworth David, great teacher, great geologist, who went south with Shackleton. Two years of postgraduate work at Cambridge, England, also left their mark, with their many contacts and European travel. From Cambridge chance led Grif to Antarctica as chief geologist on Captain Scott's last expedition. This unique experience did more than any other to develop Grif's numerous intellectual and practical talents and to harden his character. Understandably Professor Sanderson devotes more space to this episode than to any other.

The remainder of the biography is essentially part of the history of geography as an academic discipline, a discipline established by Grif at the University of Sydney (1920-29) and against all the odds. Internationally respected through his writing, he was offered and accepted a chair of geography in Chicago (1929-35), a post that turned out to be not entirely congenial. At heart he was a British Empire man; more importantly he hated not being number one in the department. Finally this ambition too was realised, with an offer to set up a new department of geography at Toronto, the first ever in Canada. With it went an appropriate salary and lifestyle. Recognised by all as the leading exponent of the 'determinist' school of geography, respected as a first-rate teacher, admired by his students, his cup of happiness seemed full. Later, back home enjoying retirement in Australia, a hint of bitterness enters his diaries - a lack of recognition by the Old Country; no knighthood (like Wright and Priestley), no gold medals. Professor Sanderson makes no serious attempt to explain these apparent snubs. Was he after all 'too versatile to be sound'? One correction and one criticism in conclusion: on page 39 James Simpson, Grif's Canadian friend at Cambridge, appears to be confused 